Gordana Ivankovič ${ }^{1}$

Sandra Janković ${ }^{2}$

UDK 65.015.25:640.41>(497.4)

Milena Peršić ${ }^{3}$

Original scientific paper

Izvorni znanstveni rad

\title{
FRAMEWORK FOR PERFORMANCE MEASUREMENT IN HOSPITALITY INDUSTRY - CASE STUDY SLOVENIA
}

\begin{abstract}
Hotel organizations in transition economies must create effective competitive methods for survival, since they exist in an environment where both customer and investor are demanding more from every organization. In search of solutions they should use performance measurement system that meets the requirements of a changed environment.
\end{abstract}

The aim of this paper is to present how developed is performance measurement in hotel organizations in Slovenia. The article is based on the research carried out in Slovenia in hotels with over 100 rooms. First the necessary information for various decision-making levels will be introduced together with the criteria for efficiency measurement and then the basic hypothesis will be tested by relevant statistical methods.

Key words: Performance Measurement, Financial and non-Financial Measures, Hotel industry,

\section{INTRODUCTION}

Outdated performance measurement systems were found to produce misleading cost numbers and performance measures. Radical changes in manufacturing technology and philosophy, combined with intensified global competition and more demanded customers, have made many traditional systems obsolete. In response, significant efforts have been made in both industry and academe to conceive and apply new performance measurement system, needed for making decisions.

The idea is substantiated by the fact that companies and other organisations also have social responsibility, which reaches beyond generating money for shareholders. If the interests of all the stakeholders (management, employees, customers, suppliers, the government and wider communities) are not taken into consideration, such groups could turn away from co-operating with a company, which could threaten its future performance. The operating circumstances on the one hand, which have changed in the past decade because of advances in technology - particularly IT - and the political changes on the other, brought about the globalisation of business (Kavčič and Ivankovič, 2004b: 134).

An adequate performance measurement system helps the management to meet their customers' demand and achieve business objectives (Damonte et al., 1997). Chenhall and Morris (1986) and Mia and Chenhall (1994) state, that information are strongly needed, since it helps the management to pass valuable decisions, thus contributing to better achievements (cf. also Downie, 1997). Performance measurement system must therefore supply information that the management is asking for (Dent, 1996; Govidarajan, 1984; Mia and Chenhall, 1994; Simons, 1990).

\footnotetext{
${ }^{1}$ University of Primorska, Faculty of Tourism Studies Portorož - Turistica, gordana.ivankovic@turistica.si

${ }^{2}$ Faculty of Tourism and Hospitality Management Opatija, sandra.ilic@fthm.hr

${ }^{3}$ Faculty of Tourism and Hospitality Management Opatija, milena.persic@fthm.hr
} 


\section{THE CHARACTERISTICS OF HOTEL BUSINESS}

Hotel business is a multifaceted sector, which product and service elements are interrelated and complex. Services in the hotel industry are complex, personal, intangible, heterogeneous and simultaneous. (Jones and Lockwood, 1989; Fitzgerald et al., 1991). The same can be said about the products, which summarize elements of services, as well as those of retail and manufacturing. (Harris, 2006) An idea gaining ground (Brander Brown and Atkinson, 2001: 130 ) is that the key factor of success in the hotel industry is focus on people: employees and guests. $^{4}$

Harris defines the accommodation or rooms department of a hotel as pure service. The Beverage department encompasses restaurants and bars of various types and involves service, retail function comprising the merchandising and stock management. The Food department similarly constitutes a service industry product, but in addition to stock management, also comprises a production function, involving the purchase and conversion of raw materials into finished products, i.e. dishes and meals for distribution and service to guests. (Harris, 2006). Figure 1

\section{The hotel Product}

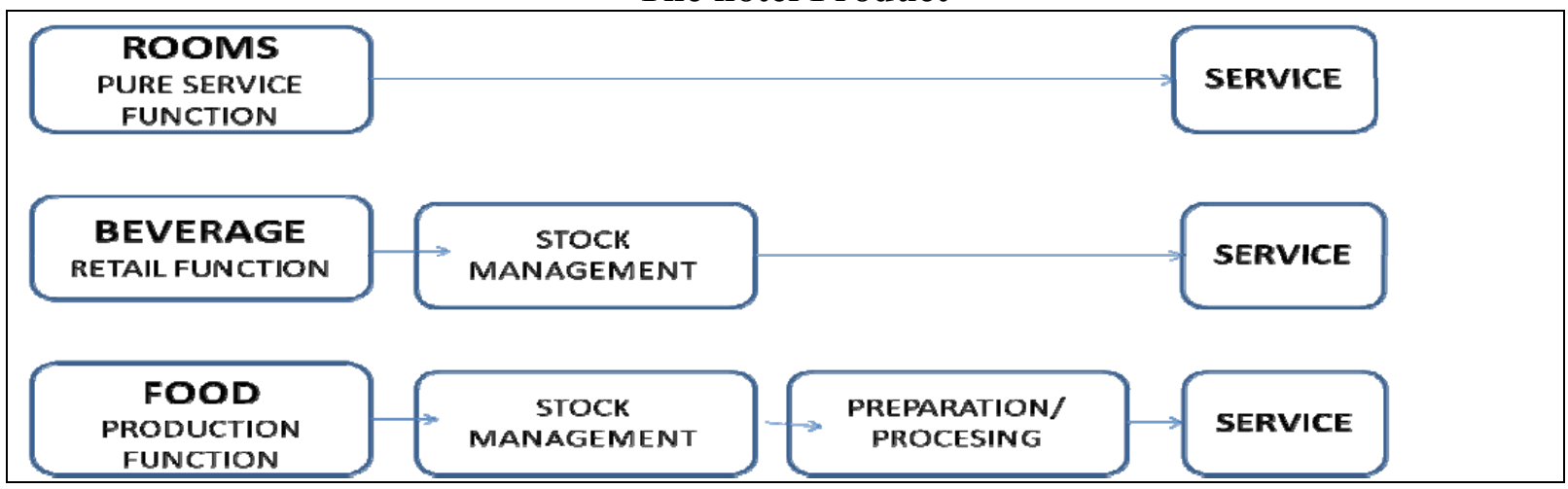

Source: Harris, P., The profit planning framework: applying marginal accounting techniques to hospitality services, in: Accounting and Financial Management, Elsevier, 2006, p.139

Business decisions in hotel companies are of very special nature and different from those in other business organizations, due to the special character of their activities. Hotel companies usually work in a very competitive environment. Competition brings about threats, as well as opportunities. Proactive companies study their environment very carefully and take into consideration all the economic, social and technological changes, accepting them as opportunities and challenges (Rolfe, 1992: 33). As hotels prepare a new product on the basis of the opportunities perceived, the new idea is often copied by competitor hotels, which shortens the useful life of such product or service. Hotels that are market leaders must therefore constantly progress if they want to keep their cutting edge. New competitors can easily enter the hotel industry, since almost every hotel is able to manipulate prices through special discounts and packages. Managements are aware that hotels need to catch the interest of customers, turning customer satisfaction into a priority. If they want to be successful at it, they have to know their competition well and know which differentiated products or services (at low costs) can be their competitive advantage. Hotels will be able to ensure long-term success, if they have satisfied customers that keep returning and thus contributing to hotels' good performance. Another key factor for every hotel are the business strategy adopted, alongside with Strategic Management Accounting (SMA), which supplies information for monitoring the implementation of the business strategy.

\footnotetext{
${ }^{4}$ Also rising is the belief that hotels need a higher level of information among employees, since the employee's morale and customer satisfaction are two key areas.
} 
The business environment in the hotel industry is characterised by fierce competition and constantly changing circumstances. Each hotel is in direct or indirect competition with every other hotel. Strong competition forces the management to try to get closer to their guests' wishes, since it is the only way to achieve success. Numerous authors claim that the lodging industry lacks a sufficiently developed management accounting system (MAS) (Phillips, 1999; Mia and Patiar, 2001; Banker et al., 1999; Brander Brown and McDonnell, 1995 and others), which could offer valid information for adopting relevant decisions.

\section{DEFINING PERFORMANCE MEASUREMENT}

Performance measurement is the process of quantifying action, where measurement is the process of quantification and action leads to performance (Neely et al, 1995). It has been in existence in hospitality industry for a long time as an important component of the decisionmaking process. Performance measurement offer hotel managements the possibility to make decisions that could ensure the best possible results, taking into account the special characteristics of the hotel business. Such special features show in the high share of fixed costs in overall expenses and in the need to be focused on marketing (Brander Brown and Harris, 1998; Kotas, 1975; Harris, 1995). Traditional performance measurement has been criticized for creating single focus and short-term orientation, lacking strategic focus, discouraging continuous improvement.

The starting point for creating an adequate performance measurement system is to know the objectives of an individual hotel and the strategies to achieve them (Geller, 1985a, b, $\mathrm{c}^{5}$; Brotherton and Shaw, 1996, Croston, 1995; Jones, 1995; Brander Brown, 1995) and the recognition of the factors that are of critical importance for the achievement of the objectives. If we equal success with achieving goals, we can say that the critical factors for achieving objectives are the same as the CSFs.

Since the demand for computerised information needed for budgeting, making decisions, supervising and comparing, performance measurement system proves to be an important reason for introducing a high-quality IT system. Such a system will not ensure the results wanted if the responsibilities for making decisions are not clearly divided among the various levels of management before the introduction of an IT system. Hotels usually have different decision-making levels. Managers at each level make decisions within their areas of competence and responsibility. Performance measurements must supply information to each decision-making level that is customised for the purpose and the subject of decisions. We believe that performance measurement information is useful as much as the management are satisfied with them. If the information is not supplied on time, the management will not use it, even if it would like to do so. The opposite is also true: If the management are not satisfied with the information supplied, they will not use them (Kavčič and Ivankovič, 2004a: 550).

Kaplan and Norton (1992) have proven that organisations operating in today's dynamic circumstances need to resort to different criteria (financial and non-financial indicators and indices) and also take into account multiplication performance measures. Only by taking into account both financial and non-financial measures, such as profitability, customer satisfaction, response time, team work and productivity, we are able to create a consistent performance measurement system that will also offer a more effective system of supervision. The lodging industry is a people-oriented industry. The economic and financial success of a hotel therefore depends on the attitude and behaviour of employees, the development of new products and services, as well as on customer satisfaction. Hotel companies must think of their performance in a wider sense (from the point of view of

\footnotetext{
5 By taking into consideration the characteristics of individual companies, Geller identified the goals that are typical of the entire industry, such as critical success factors (CSF) and criteria.
} 
employees, customers, suppliers, management etc) and not only from a merely financial perspective, which is only the epitome of all the aspects of success. Hotel General and Department Managers must recognise equal importance to the goals of all the stakeholders and not only of their shareholders. The achievement of the objectives of all the stakeholders (i. e. guests, employees, strategic partners, community) can be measured by both financial and non-financial measures.

After having taken into consideration the theoretical assumptions, we have formulated our basic hypothesis that hotels with an adequate Performance measurement system perform better than those without one.

In order to test our hypothesis, we first had to define what an adequate performance measurement system should look like. We have made the claim that a company has an adequate performance measurement system, if it meets the following requirements:

1. General Managers (GMs) and Department Managers (DMs) ${ }^{6}$ of the hotel:

1a) use the performance measurement information frequently;

1b) both management levels are satisfied with the timeliness and usefulness (contents) of the information.

2. When evaluating their performance, top management and heads of units of a hotel pay equal attention to monetary and non-monetary measures.

3. The hotel:

3.a) has a well-defined business strategy - measured by its mid-term budget ( 3 years or more); and

3.b) uses Strategic Management Accounting for making decisions - measured by its own market share and the market shares of its main competitors and their prices.

We were also aware that Slovenian hotels may fulfil one, two or all the conditions above. For this reason, we had to counter balance some of the conditions. Having made a thorough analysis of the importance of individual factors, we agreed that it would be better to compare factors with comparable importance. The next step in our analysis was to check whether Slovenian hotel companies have performance measurement system. This would enable us to conclude whether inadequate performance measurement systems are to be blamed for the poor performance of some Slovenian hotels. The analysis of such verification is given below.

\section{METHODOLOGY}

The questionnaire for hotel managements was divided into eight chapters: general information on the hotel, use of performance measurement information at various level of decision-making, marketing information, information about the employees, company owners and IT systems, implementation of SMA and methods used for budgeting. Questionnaires were sent to 51 hotels, which accounts for all the hotels in Slovenia with more than 100 rooms. The questionnaires were filled out by 39 hotels or $76 \%$ of the entire section of the industry. ${ }^{7}$ Of all the hotels included, $61 \%$ have three stars, the others have four.

\footnotetext{
${ }^{6}$ Food \& Beverage Departments and Rooms Department

7 Hotels who did not answer are located in different parts of Slovenia and differ in size. This means that the unanswered questionnaires do not imply that hotels of a certain size or in a certain region in Slovenia have been left out .
} 


\subsection{CRITERIA FOR EVALUATING VARIABLES}

Consistently with the definition of the development level of performance measurement system and their importance for the performance of a company, we also had to define our relative and absolute variables.

\subsubsection{Definition of independent variables}

1) We measured the importance of performance measurement information in making business decisions separately in the case of hotel General and Department managers through:

a) Frequency of use of performance measurement information ${ }^{8}$ in taking short- and longterm business decisions (condition 1a)

b) Satisfaction with the timeliness and usefulness of performance measurement information $^{9}$ (condition $1 \mathrm{~b}$ ); and

2) Evaluation of the importance of goals ${ }^{10}$, which we adapted from Kaplan's and Norton's BSC (1992) (condition 2).

3) The hotel has a well-defined business strategy and SMA, if it has a long-term strategy, a consequent strategic plan for three or more years, and if it follows its own market share and the market shares of its main competitors, as well as their prices (condition 3).

\subsubsection{Definition of dependent variables}

We have defined the business performance of a hotel to be a dependent variable, measured by financial and non-financial measures.

1) In order to guarantee comparability, we have chosen two financial indicators in the period of the preceding five years and we have de-flationed the figures: average net sales revenues per room (USALI, 2006; Kwansa and Schmidgall, 1999: 90) and average profit or loss per room.

2) Among the non-financial criteria we have taken into consideration: the number of new products in the preceding two years, the average share of return guests in the preceding five years (Foster et al., 1996) and the average number of employees per room in the period of the preceding five years (USALI, 2006).

\section{RESULTS}

We started by verifying the first condition to be met by a hotel, if we are to say that it has a developed performance measurement system. So, we first checked how frequently performance measurement information is used in Slovenian hotels by directors and heads of units for taking short- and long-term decisions. By applying the reliability rate of a measuring scale (Cronbach's alpha), we first verified the internal consistency of the measuring scale, composed by the variables used to check the frequency of use of performance measurement

\footnotetext{
${ }^{8}$ The frequency of use of performance measurement information was measured by using a five-degree scale of importance (ranging from 1-never to 5-very often), previously used by Mia and Patiar (2001); ibid. also Chenhall and Morris (1986); Mia and Clarke (1999); Simons (1990). We measured the use of information in five different units separately: effectiveness of advertising and marketing, prices of products and services, booking systems and marketing strategies, customer satisfaction and profitability of units.

9 The level of satisfaction with information was measured with a five-degree scale, ranging from 1-not satisfied to 5 -very satisfied.

10 We have grouped the goals in financial (monetary achievements and results compared to the budget) and nonfinancial goals (customer complaints, fluctuations in staff numbers and quality of services).
} 
information. We obtained a high value for the rate (0.92), which proves that the variables have been chosen correctly.

\section{Table 1.}

Use of performance measurement information for taking short- and long-term decisions

\begin{tabular}{|l|c|r|r|r|}
\hline VARIABLES & Decision-making level & AM-S & AM-L & AM-Total \\
\hline Effectiveness of & GMs & 3.9 & 4.1 & 4.0 \\
promotion and sales & DMs & 3.1 & 3.2 & 3.1 \\
\hline Costs of goods and & GMs & 4.5 & 4.5 & 4.4 \\
services & DMs & 3.7 & 3.7 & 3.7 \\
\hline Booking system and & GMs & 3.7 & 4.0 & 3.9 \\
marketing strategy & DMs & 3.2 & 3.2 & 3.3 \\
\hline \multirow{2}{*}{ Guest satisfaction } & GMs & 4.5 & 4.6 & 4.5 \\
\hline Profitability of & DMs & 4.2 & 4.1 & 4.1 \\
department & GMs & 4.3 & 4.6 & 4.5 \\
\hline \multirow{2}{*}{ TOTAL } & DMs & 3.5 & 3.6 & 3.6 \\
\hline TOTAL $(G M+D M)$ & DMs & 4.2 & 4.4 & 4.3 \\
\hline
\end{tabular}

Legend:

GMs $=$ General Managers; DMs $=$ Department Managers of Food \& Beverage and of Rooms

$\mathrm{AM}-\mathrm{S}=$ arithmetic mean of a short-term decision; $\mathrm{AM}-\mathrm{L}=$ arithmetic mean of a long-term decision

Table 1 shows that (condition 1a), on average, General and Department Managers of hotel use the information for taking decisions with the same frequency, which is above average, since the arithmetic mean was 3.9 on a five-degree scale. General and Department Managers do not show considerable statistic differences in using information on customer satisfaction $(\mathrm{t}=0.96$; $\mathrm{p}>0.5$ ) for making short- and long-term decisions.

Table 2 shows the levels of satisfaction with the performance measurement information, in terms of timeliness and usefulness (contents) of the information supplied to General and Department Managers (condition 1b)

Table 2.

\section{Satisfaction of hotel management's with the timeliness and usefulness of MAS information}

\begin{tabular}{|l|c|r|}
\hline VARIABLES & Decision-making level & AM \\
\hline Timeliness of MAS & GMs & 3.9 \\
information & DMs & 3.4 \\
\hline Usefulness (contents) & GMs & 4.0 \\
of MAS information & DMs & 3.5 \\
\hline \multirow{2}{*}{ TOTAL } & GMs & 3.9 \\
& DMs & 3.5 \\
\hline TOTAL & $(\mathrm{GM}+\mathrm{DM})$ & 3.7 \\
\hline
\end{tabular}

The table shows that General Managers tend to be more satisfied with the timeliness and usefulness of information than the Department Managers. Both groups show a combined rate of $74 \%$.

The second condition for having an adequate performance measurement system, is to pay the same level of attention to financial and non-financial goals when General and Department 
Managers evaluate the performance of their hotel. When checking the difference between General and Department Managers in terms of goal importance, we see a considerable statistical difference between General and Department Managers in giving more importance to financial goals than to non-financial ones $(t=3.97 ; \mathrm{p}<0.5)$, while there are no statistically relevant differences between the treatment of non-financial goals by General and Department Managers $(\mathrm{t}=-0.176 ; \mathrm{p}>0.5)$ The arithmetic mean of the answers on a five-degree scale is shown in Table 3.

Table 3.

Importance of financial and non-financial goals for hotel General and Department Managers

\begin{tabular}{|l|c|r|}
\hline VARIABLES & Decision-making level & AM \\
\hline Financial & GMs & 4.2 \\
goals & DMs & 3.4 \\
\hline Non-financial & GMs & 4.2 \\
goals & DMs & 4.2 \\
\hline \multirow{2}{*}{ TOTAL } & GMs & 4.2 \\
& DMs & 3.8 \\
\hline TOTAL & $(\mathrm{GM}+\mathrm{DM})$ & 4.0 \\
\hline
\end{tabular}

The data show that top management, i.e. General Managers, pay the same amount of attention to financial and non-financial goals, while heads of units tend to be more focused on nonfinancial than on financial objectives. The results make sense, since Department Managers are faced with non-financial issues (customers' complaints, fluctuations of staff and quality of services) on a daily basis, while financial questions are more remote to them.

The third condition is composed of a well-defined business strategy and the use of SMA. Business strategy was defined as the adoption of a long-term strategy, while SMA meant that the management knew their market share and the market shares of their main competitors along with their prices.

The analysis of the answers received is shown in Table 4.

Table 4.

Use of SMA and definition of business strategy

\begin{tabular}{|l|r|}
\hline VARIABLES & AM \\
\hline Long-term strategy & 3.8 \\
\hline Knowing one's own market share & 3.5 \\
\hline Knowing the market shares of the major competitors & 3.0 \\
\hline Knowing the prices of the main competitors & 4.6 \\
\hline TOTAL & 3.7 \\
\hline
\end{tabular}

The figures show that most Slovenian hotels meet the third condition for a good performance measurement system. The level of compliance with the three conditions is shown in Table 5. 
Table 5.

Level of development of performance measurement system in Slovenian hotels

\begin{tabular}{|l|r|}
\hline Condition & AM \\
\hline Frequency of use of information (1a) & 3.9 \\
\hline Utility of information (1b) & 3.7 \\
\hline Use of monetary and non-monetary measures (2) & 4.0 \\
\hline Long-term strategy and SMA (3) & 3.7 \\
\hline TOTAL & 3.8 \\
\hline
\end{tabular}

If we consider the presence of all the conditions, we can conclude that $74 \%$ of hotels have a well-developed performance measurement system. The level of development in Slovenian hotels indicates that they should be successful.

The following step was to verify whether the hotels with a good performance measurement system perform better than those that do not. In order to answer this question, we gathered information on the average performance of the hotels surveyed in the preceding five years. In line with the definition of performance measures, the financial and non-financial measures are shown in Table 6 . We have divided the hotels in coastal, thermal-spa and others.

Table 6.

Hotel performance measures

\begin{tabular}{|l|r|r|r|r|r|}
\hline Type of hotel & $\begin{array}{c}\text { Net revenue } \\
\text { per room (in } € \text { ) }\end{array}$ & $\begin{array}{c}\text { Net profit per } \\
\text { room (in } € \text { ) }\end{array}$ & $\begin{array}{c}\text { Number of emplo- } \\
\text { yees per room }\end{array}$ & $\begin{array}{c}\text { Portion of } \\
\text { return guests }\end{array}$ & $\begin{array}{c}\text { Number of } \\
\text { new products }\end{array}$ \\
\hline Thermal baths & 17,283 & 1,933 & 0.68 & 0.15 & 10 \\
\hline Coastal & 16,233 & 2,004 & 0.54 & 0.04 & 8 \\
\hline Other & 12,142 & $-1,104$ & 0.37 & 0.15 & 1 \\
\hline
\end{tabular}

The data indicate that thermal-bath hotels are the most successful in terms of net sales revenues per room, while the others do not perform that well. Thermal-bath hotels also tend to have a larger number of new products. In terms of profit or loss and a lower number of employees per room, the coastal hotels are more successful than the thermal baths. Other hotels tend to achieve the worst financial results, in spite of having, on average, fewer employees per room.

According to our hypothesis that hotels with a good performance measurement system tend to perform better, the figures would indicate that thermal-bath and coastal hotels have good performance measurement system, while the others have not. Therefore, the next step was to verify the level of development in the different types of hotels. We have discovered that thermal-bath hotels have comparably developed systems (3.82 on a five-degree scale), followed by coastal hotels (3.80 on a five-degree scale), while the other hotels are in the last position (3.23 on a five-degree scale). The result proves that the hotels with better developed performance measurement system do perform better than those without one.

Since several equally important factors have been taken into consideration in defining an adequate performance measurement system, we had to verify the connections between individual factors of performance measurement system development with result. For this purpose, we have calculated the Pearson's correlation rate. The results have shown that none of the measurement factors can considerably affect the level of success. Neither rate that we have calculated has exceeded the value of 0.0368 . The only factor to achieve this value was the correlation rate between net sales revenues per room and the frequency of use of a performance measurement system for making long-term decisions by hotel General Managers. The rates calculated therefore have no explanatory value. The results have 
confirmed our expectations, since figures on the business result of Slovenian hotels show that most of them perform poorly, in spite of having relatively well-developed performance measurement system.

\section{DISCUSSION}

Figures show that in most cases Slovenian hotels show poor economic performance. This could lead us to say that they have inadequately developed performance measurement systems. The analysis of the answers showed that the average level of development is comparably good, since it reaches 3.8 on a five-degree scale.

The fundamental assumption of our paper was that the hotels with better developed performance measurement system perform better than those without one. The hypothesis has been only partially proven. Thermal-bath hotels have the highest net sales revenues per room and the largest number of new products. Coastal hotels have the highest profit per room and the lowest number of employees per room. Both types of hotels have performance measurement system at similar levels of development, while the other hotels, with less developed system, also tend to perform worse. When we verified the correlations between individual factors of system development against business result, we did not find any. We have to conclude therefore that the development of performance measurement system does not affect the performance of Slovenian factors as other factors do. This conclusion has also been proven in the case of thermal-bath hotels. The reason for their success is mostly their monopolistic position in the market, since most of their guests are supplied by the government's Health Insurance Institute. The hotels have agreements stipulated with the Institute, on the basis of which they have better occupancy rates, revenues and cash flows. The agreements also guarantee prices and timely payments. For this reason, the thermal baths pay less attention to costs and achieve lower profits in spite of higher revenues. The opposite can be said about the coastal hotels, which operate in market conditions and therefore have to be more focused on managing costs. For this reason, they have better profits per room in spite of lower revenues per room. Thermal-bath hotels use their performance measurement system mostly to define the prices for their services that can be charged to the Health Insurance Institute.

The results of our research of Slovenian hotels failed to confirm our hypothesis, which is something unusual. There have been many researches published in the world about the issue that we have investigated in Slovenia and their conclusions were that performance measurement system development levels affect the business results of hotels. (Brander Brown and McDonnell, 1995; Mia and Clarke, 1999; Mia and Patiar, 2001; Brander Brown and Atkinson, 2001; Phillips, 1999; Denton and White, 2000; Huckestein and Duboff, 1999; Collier and Gregory, 1995; Dunn and Brooks, 1990; Noone and Griffin, 1997; Brotherton and Shaw, 1996; Croston, 1995; Jones, 1995). One reason for different results in Slovenia is probably due to the fact that in the system of self-management socialism - in force in Slovenia up until 1990 - there was no global competition, which would force companies to weight the positive and negative sides of individual business decisions. The need for considerate decision-making based on adequate information only made its appearance in Slovenia once the economic system has been changed in all the companies, including hotels. Hotels, as other companies as well, gather information for making decisions. The question remains, whether such pieces of information are relevant and whether they are being used. An answer to this question will have to be given by future studies. 


\section{LITERATURE}

1. Banker, R., Potter, G. and Srinivasan, D. (1999) An empirical investigation of an incentive plan based non-financial performance measures. The Accounting Review.

2. Banker, R., Potter, G. and Srinivasan, D. (1999) An Empirical Investigation of an Incentive Plan Based Non-financial Performance Measures. The Accounting Review

3. Brander Brown, J. and Atkinson, H. (2001) Rethinking Performance Measures: Assessing Progress in UK Hotels. International Journal of Contemporary Hospitality Management 13(3), 128-135.

4. Brander Brown, J. and Harris, P. J. (1998) Organisational Culture and Control in a Strategic Planning Context: Implications for the International Hospitality Industry. In Teare, R., Farber, B. and Brown, G. (eds.) Global Directions for Hospitality and Tourism Development. London: Cassell, 105-131.

5. Brander Brown, J. and McDonnell, B. (1995) The Balanced Score-card: Short-term Guest or Long-term Resident? International Journal of Contemporary Hospitality Management 7(2-3), 7-11.

6. Brander Brown, J. (1995) Management Control in the Hospitality Industry: Behavioural Implications. In Harris, P. J. (ed.) Accounting and Finance for the International Hospitality Industry. Oxford: Butterworth-Heinemann, 183-201.

7. Brotherton, B. and Shaw, J. (1996) Towards an Identification and Classification of Critical Success Factors in UK Hotels plc. International Journal of Contemporary Hospitality Management 15(2), 113-135.

8. Chenhall, R. and Morris, D. (1986) The Impact of Structure, Environment and Interdependence on the Perceived Usefulness of Management Accounting Systems. The Accounting Review LXI(1), 16-35.

9. Collier, P. and Gregory, A. (1995) The Practise of Management Accounting in Hotel Groups. In Harris, P. J. (ed.) Accounting and Finance for the International Hospitality Industry. Oxford: Butterworthe-Heinemann, 137-159.

10. Croston, F. J. (1995) Hotel Profitability: Critical Success Factors. In Harris, P. (ed.) Accounting and Finance for the International Hospitality Industry. Oxford: Brookes University, 295-315.

11. Damonte, L., Rompf, P., Bahl, R. and Domke, D. (1997) Brand Affiliation and Propery Size Effects on Measures of Performance in Lodgings Industry. Hospitality Research Journal 20(3), 1-16.

12. Dent, J. (1996) Global Competition: Challenges for Management Accounting and Control. Management Accounting Research 7, 247-269.

13. Denton, G. A. and White, B. (2000) Implementing a Balanced-scorecard Approach to Managing Hotel Operations. Cornell Hotel and Restaurant Administration Quarterly 2, 94-107.

14. Downie, N. J. (1997) The Use of Accounting Information in Hotel Marketing Decisions. International Journal of Hospitality Management 16(3), 305-312.

15. Dunn, K. D. and Brooks, D. E. (1990) Profit Analysis Beyond Yield Management. Cornell Hotel and Restaurant Administration Quarterly 31(3), 80-90.

16. Fitzgerald, L., Johnston, R. S., Brignall, T. J., Silvestro, R. and Voss, C. (1991) Performance Measurement in Service Businesses. London: Chartered Institute of Management Accountants.

17. Foster, G., Gupta, M. and Sjoblom, L. (1996) Customer Profitability Analysis: Challenges and New Directions. Cost Management (Spring), 5-17. 
18. Foster, G., Gupta, M. and Sjoblom, L. (1996) Customer Profitability Analysis: Challenges and New Directions. Cost Management (Spring), 5-17.

19. Geller, A. N. (1985a) Tracking the Critical Success Factors for Hotel Companies. The Cornell Hotel and Restaurant Administration Quarterly, February, 76-81.

20. Geller, A. N. (1985b) The Current State of Hotel Information Systems. The Cornell Hotel and Restaurant Administration Quarterly, May, 14-17.

21. Geller, A. N. (1985c) How to Improve Your Information System. The Cornell Hotel and Restaurant Administration Quarterly, August, 19-27.

22. Govindarajan, V. (1984) Appropriateness of Accounting Data in Performance Evaluation: An Empirical Examination of Environment Uncertainty as an Intervening Variable. Accounting Organisation and Society 9(2), 125-136.

23. Harris, P. J. (1995) A Development Strategy for the Hospitality Operations Management Curriculum. International Journal of Contemporary Hospitality Management 7(5), 29-32.

24. Harris, P., (2006) The profit planning framework: applying marginal accounting techniques to hospitality services, in: Accounting and Financial Management, Elsevier, 137-150

25. Huckestein, D. and Duboff, R. (1999) Hilton Hotels: A Comprehensive Approach to Delivering Value for All Stakeholders. The Cornell Hotel and Restaurant Administration Quarterly, August 28-38.

26. Ivankovič, G. (2004) Računovodsko merjenje uspešnosti poslovanja v hotelirstvu: doktorska disertacija. Ljubljana: Ekonomska fakulteta.

27. Jones, T. A. and Lockwood, A. (1998) Operations Management Research in the Hospitality Industry. International Journal of Hospitality Management 17, 183-202.

28. Jones, T. A. (1995) Identify Managers Information Needs in Hotel Companies. In Harris, P. J. (ed.) Accounting and Finance for the International Hospitality Industry. Oxford: Butterworth-Heinemann, 163-182.

29. Kaplan, R. S. and Norton, D. P. (1992) The Balanced Scorecard: Measures that Drive Performance. Harvard Business Review, 71-79.

30. Kavčič, S. and Ivankovič, G. (2003) Raziskovalno poročilo: Vzpostavljanje razmer za pridobivanje računovodskih in drugih podatkov potrebnih za metodologijo USALI v Sloveniji.

31. Kavčič, S., Ivankovič, G., Klobučar, N. and Vidic, D. (2001) Raziskava Analiza možnosti spremljanja uspešnosti poslovanja po metodologiji Horwath v slovenskih hotelskih podjetjih. Ljubljana: Ekonomska fakulteta.

32. Kavčič, S. and Ivankovič, G. (2004b) Performance measurement in the hotel industry. In: Tourism in the process of the european integration and globalisation. Bratislava, 134-140.

33. Kavčič, S. and Ivankovič, G. (2003) Vzpostavljanje razmer za pridobivanje računovodskih in drugih podatkov potrebnih za metodologijo USALI v Sloveniji. Ljubljana: Ekonomska fakulteta, Inštitut za računovodstvo in revizijo.

34. Kotas, R. (1975) Market Orientation in the Hotel and Catering Industry. London: Survey University Press, 1-57.

35. Kwansa, F. and Schmidgall, R. S. (1999) The Uniform System of Accounts for the Lodging Industry. The Cornell Hotel and Restaurant Administration Quarterly, December, 88-94.

36. Mia, L. and Patiar, A. (2001) The use of management accounting systems in hotels: an exploratory study, International Journal of Hospitality Management 20, 111-128.

37. Mia, L. and Chenhall, R. (1994) The Usefulness of MAS Functional Differentiation and Management Effectiveness. Accounting, Organization and Society 19(1), 1-13.

38. Mia, L. and Clarke, B. (1999) Market Competition, Management Accounting Systems and Business Unit Performance. Management Accounting Research 10(2), 137-158. 
39. Mia, L. and Patiar, A. (2001) The Use of Management Accounting Systems in Hotels: An Exploratory Study. International Journal of Hospitality Management 20, 111-128.

40. Noone, B. and Griffin, P. (1997) Enhancing Yield Management with Customer Profitability Analysis. International Journal of Contemporary Hospitality Management 9(2), 75-79.

41. Peršić, M., Janković, S. (2006) Menadžersko računovodstvo hotela, Fakultet za turistički i hotelski menadžment, Opatija, HZRFD, Zagreb

42. Phillips, P. A. (1999) Performance Measurement System and Hotels: A New Conceptual Framework. International Journal of Hospitality Management 18(2), 171-182.

43. Rolfe, A. J. (1992) Profitability Reporting Techniques Bridge Information Gap. The Journal of Business Strategy 13(1), 32-37.

44. Simons, R. (1990) The Role of Management Control Systems in Creating Competitive Advantage: New Perspective. Accounting, Organizations and Society 15, 127-143.

45. Uniform System of Accounts for the Lodging Industry. Ninth Edition (2006). New York: Educational Institute of the American Hotel \& Motel Association.

\section{OKVIR MJERENJA UČINKOVITOSTI U HOTELIJERSTVU - SLUČAJ SLOVENIJE}

Hotelske organizacije u tranzicijskim gospodarstvima moraju stvarati efikasne konkurentne metode preživljavanja jer se nalaze u okruženju u kojem i klijenti i investitori traže sve više od svake organizacije. U potrazi za rješenjima trebali bi koristiti sustav mjerenja učinkovitosti koji je u skladu s izazovima izmijenjenog okruženja.

Cilj ovog rada je prezentirati koliko je razvijeno mjerenje učinkovitosti u hotelskim organizacijama u Sloveniji. Rad se zasniva na istraživanju provedenom u Sloveniji u hotelima s višse od 100 soba. Prvo uvodimo potrebne informacije za različite razine odlučivanja zajedno s kriterijima za mjerenje efikasnosti a potom se relevantnim statističkim metodama testira osnovna hipoteza.

Ključne riječi: Mjerenje učinkovitosti, financijske i ne-financijske mjere, hotelijerstvo 